\section{Resistance in Muskmelon Cultivars to Melon Aphid}

\author{
J.K. Collins and P. Perkins-Veazie \\ U.S. Department of Agriculture, Agricultural Research Service, South Central \\ Agricultural Research Laboratory, Lane, OK 74555
}

\section{N. Maness \\ Department of Horticulture, Oklahoma State University, Stillwater, OK 74078 \\ B. Cartwright \\ Department of Entomology, Oklahoma State University, Wes Watkins Agricultural Research and Extension Center, Lane, OK 74555}

\section{Additional index words. Cucumis melo, Aphis gossypii}

The melon aphid (Aphis gossypii Glover) causes direct-feeding damage on muskmelon (Cucumis melo L.) plants and vectors plant viruses (Kishaba et al., 1992), which can result in plant death. The melon aphid also excretes honeydew on the fruit, which serves as a growth medium for sooty mold (Capnodium sp.) (Goff and Tissot, 1932). Fruit with more than slight amounts of sooty mold are considered unmarketable (U.S. Dept. of Agriculture Marketing Service, 1981).

Use of insect-resistant cultivars can be useful in integrated pest management programs to minimize pesticide applications. Melon cultivars bred for melon aphid resistance have been released (McCreight et al., 1984) with limited commercial success. Preliminary data indicated natural resistance among commercially important muskmelon cultivars. The objective of this study was to identify commonly grown muskmelon cultivars having tolerance or resistance to melon aphid.

'Hymark' (Petoseed, Saticoy, Calif.), 'Magnum 45' (Petoseed), and 'Mission' (Asgrow, Kalamazoo, Mich.) muskmelon were evaluated for resistance in 1990; 'Sweet Surprise' (Sakata Seed America, McAllen, Texas) was evaluated only in 1991. In both years, plants were grown in field plots at the South Central Agricultural Research Laboratory, Lane, Okla. Each cultivar was grown under naturally aphidinfested conditions [treated with (3-phenoxyphenyl)methyl 3-(2,2-dichloroethenyl)-2,2dimethylcyclopropanecarboxylate (permethrin) (Pounce 25wp; FMC Corp., Philadelphia) at $0.11 \mathrm{~kg} \cdot \mathrm{ha}^{-1}$ to kill aphid predators and parasitoids] and noninfested regimes [treated with oxydemeton-methyl (Metasystox; Miles, Kansas City, Mo.) at $0.55 \mathrm{~kg} \cdot \mathrm{ha}^{-1}$ ]. A split-plot design was used with insecticide treatments as

Received for publication 17 Mar. 1994. Accepted for publication 28 June 1994. Mention of a trademark, proprietary product, or vendor does not constitute a guarantee or warranty of the product by the U.S. Dept. of Agriculture and does not imply its approval to the exclusion of other products of vendors that may also be suitable. The cost of publishing this paper was defrayed in part by the payment of page charges. Under postal regulations, this paper therefore must be hereby marked advertisement solely to indicate this fact. main plots and cultivars as subplots. Each subplot consisted of five transplants replicated in four blocks (a total of 20 plants). The number of aphids on five leaves per plot was counted weekly beginning at the four true-leaf stage and ending at first harvest. All plots were treated at 10- to 14-day intervals with tetrachloro-isophthalo-nitrile (chloro-thalonil) (Bravo; Fermenta ASC Corp., Mentor, Ohio) for foliar disease protection. Melon aphid resistance was verified in a greenhouse study in 1993. Twenty plants each of 'Mission', 'Magnum 45', 'Sweet Surprise', and 'Hymark' were infested with five to 10 aphids per plant. Plants were covered with a ventilated cylindrical cage made of polycarbonate plastic. Aphid counts were made 12 days after infestation.

Melons free of cracking or decay were harvested from plots twice weekly. The fruit were considered unmarketable if sooty mold covered $>25 \%$ of the melon's surface. Fifteen marketable, yellow fruit were evaluated for flesh color; titratable acidity; and sugar, soluble solids, and $\beta$-carotene concentrations (Collins and Perkins-Veazie, 1993; Dionix Corp.; Zscheile and Porter, 1947). Data were subjected to analysis of variance, and means were separated by LSD.

Aphid counts were higher on all nontreated plants in field plots, except for those of 'Sweet Surprise' (Table 1). Nontreated 'Sweet Surprise' and 'Hymark' plants had lower aphid counts than 'Magnum 45' or 'Mission' plants. In the greenhouse study, 'Sweet Surprise' plants were more resistant to aphids $(99 \pm 10$ SE aphids per five leaves) than 'Mission' or for aphids in 1990 and 1991.

${ }^{\mathrm{z}}$ Treated with oxydemeton-methyl aphicide.

y No data for 1990.
'Magnum 45' plants (312 \pm 45 SE, $452 \pm 80 \mathrm{SE}$ aphids per five leaves, respectively). 'Hymark' plants were intermediate in resistance (194 \pm $38 \mathrm{SE}$ aphids per five leaves). No visible evidence of virus transmission was found.

Yields, expressed as weight (Table 1), and number of fruit of 'Magnum 45' and 'Mission' were reduced in nontreated plots $(5296 \pm 782$ SE and $3558 \pm 742 \mathrm{SE}$ fruit/ha, respectively) compared to yields from 'Sweet Surprise' and 'Hymark' (7015 $\pm 1042 \mathrm{SE}$ and $6601 \pm 634 \mathrm{SE}$ fruit/ha, respectively). Nontreated plants of 'Magnum 45' and 'Mission' had 38\% fewer marketable fruit due to surface sooty mold than plants sprayed for melon aphid control (Table 1). 'Hymark' and 'Sweet Surprise' nontreated plants had few aphids; therefore, honeydew on fruit was slight, and the percentage of marketable fruit was only slightly decreased. Flesh quality, defined as color, $\beta$ carotene, soluble solids, or sugar concentrations were not affected by aphid infestation.

These results indicate that 'Sweet Surprise' and 'Hymark' muskmelon plants exhibited aphid resistance as defined by a reduced number of insects present on plants relative to the other cultivars. To our knowledge, the occurrence of natural aphid resistance with these commercially important cultivars has not been previously reported.

\section{Literature Cited}

Collins, J.K. and P. Perkins-Veazie. 1993. Postharvest changes in strawberry fruit stored under simulated retail display conditions. J. Food Qual. 16:133-143

Dionix Corporation. Dionix application note 82: Analysis of fruit juice adulterated with medium invert sugar from beets. Dionix Corp., Sunnyvale, Calif.

Goff, C.C. and A.N. Tissot. 1932. The melon aphid, Aphis gossypii Glover. Florida Agr. Expt. Sta. Bul. 252.

Kishaba, A.N., S.J. Castle, D.L. Coudriet, J.D McCreight, and G.W. Bohn. 1992. Virus transmission by Aphis gossypii Glover to aphid resistant muskmelons. J. Amer. Soc Hort. Sci. 117:248-254.

McCreight, J.D., A.N. Kishaba, and G.W. Bohn. 1984. AR Hale's Best Jumbo, AR5 and AR Topmark: Melon aphid-resistant muskmelon breeding lines. HortScience 19:309-310.

U.S. Department of Agriculture Marketing Service. 1981. United States standards for grades of cantaloups [sic]. U.S. Dept. Agr. Marketing Serv., Washington, D.C. 46 FR 63203.

Zscheile, F.P. and J.W. Porter. 1947. Analytical methods for carotenes of Lycopersicon species and strains. Analytical Chem. 19:47-51.

Table 1. Effect of aphid populations on number of marketable muskmelons from plants nontreated or treated

\begin{tabular}{|c|c|c|c|c|c|c|}
\hline \multirow[b]{2}{*}{ Cultivar } & \multicolumn{2}{|c|}{ No. aphids/five leaves } & \multicolumn{2}{|c|}{$\begin{array}{c}\text { Yield } \\
\left(\mathrm{kg}^{\prime} \mathrm{ha}^{-1} \cdot 10^{-3}\right)\end{array}$} & \multicolumn{2}{|c|}{$\%$ Marketable fruit } \\
\hline & Treated $^{z}$ & Nontreated & Treated & Nontreated & Treated & Nontreated \\
\hline Hymark & 2.8 & $24.4^{*}$ & 18.3 & 16.3 & 100 & 91.5 \\
\hline Magnum 45 & 13.4 & $178^{*}$ & 16.9 & 13.0 & 93.6 & $60.8^{*}$ \\
\hline Mission & 5.2 & $160^{*}$ & 17.9 & $8.7^{*}$ & 98.7 & $62.1^{*}$ \\
\hline Sweet Surprise ${ }^{y}$ & 1.5 & 7.7 & 13.1 & 17.3 & 100 & 98.9 \\
\hline $\operatorname{LSD}^{\mathrm{x}}$ & 7.5 & 103 & 4.9 & 5.4 & 4.7 & 16.3 \\
\hline
\end{tabular}

${ }^{x}$ Mean separation in columns by LSD; no interactions were significant $(P \leq 0.05)$.

*Indicates significant differences $(P \leq 0.05 \mathrm{LSD})$ between treated and nontreated within cultivars 